\title{
PENGUATAN PANCASILA SEBAGAI PEMERSATU BANGSA DALAM UPAYA MENCEGAH KEJAHATAN DENGAN KEKERASAN
}

\author{
oleh \\ Dr. Hj. Hernawati, RAS
}

\begin{abstract}
ABSTRAK
Pancasila sebagai dasar negara merupakan sumber dari segala sumber hukum negara. Pancasila mengarahkan kehidupan dalam sistem kekeluargaan yang harmonis, tetapi saat ini marak terjadi kekerasan yang tidak sesuai dengan Pancasila. Berdasarkan hal tersebut maka permasalahan penelitian ini adalah bagaimana implementasi penguatan Pancasila sebagai pemersatu bangsa dalam upaya mencegah kejahatan dengan kekerasan ? Dan bagaimana kendala dalam implementasi tersebut ? Penelitian bersifat deskriptif yang bertujuan menggambarkan secara tepat, sifat suatu individu atau kelompok tertentu, keadaan, gejala atau untuk menentukan ada tidaknya hubungan antara suatu gejala dengan gejala lain dalam masyarakat. Hasil penelitian ini menunjukkan kejahatan kekerasan semakin marak, penguatan Pancasila perlu diimplementasikan secara terus menerus sejak usia dini. Kendala dalam penguatan Pancasila sebagai pmersatu bangsa dalam upaya mencegah kejahatan yaitu adanya faktor internal dan ektsternal.
\end{abstract}

\section{PENDAHULUAN}

\section{Latar Belakang}

Pancasila sebagai dasar Negara dan merupakan sumber dari segala sumber hukum Negara, harus dijadikan pedoman oleh seluruh rakyat Indonesia dalam kehidupan bermasyarakat, berbangsa dan bernegara. Setiap sila Pancasila merupakan suatu kesatuan yang integral yang harus diterapkan dalam kehidupan kemasyarakatan. Pancasila akan menjadi etika yang mengarahkan kehidupan bermasyarakat, berbangsa dan bernegara dalam suasana kekeluargaan yang harmonis. Tetapi saat ini marak terjadi kekerasan sungguh sangat tidak sesuai denagn sila Pancasila, kekerasan sangat tidak beradab. Kekerasan kini dapat terjadi di mana saja bahkan di sekolah. Sekolah sebagai pusat pendidikan formal yang mengajarkan nilai dan etika dapat menjadi tempat terjadinya kekerasan. Hasil penelitian disertasi M. Djamal membuktikan fenomena tersebut. ${ }^{1}$ Kekerasan dapat terjadi di mana saja, bisa di tempat umum ataupun di tempat pribadi. Kekerasan akhirnya menjadi perbuatan kejahatan. Kejahatan dalam era ini semakin marak, karena masalah kecil dapat mengakibatkan kekerasan yang dapat berupa kekerasan phisik ataupun seksual. Manusia sebagai mahkluk sosial, tidak bisa hidup sendiri, harus saling menghormati, menghargai orang lain meskipun berbeda pendapat atau kepentingan. Kekerasan menunjukkan sikap individualistik, egois, mementingkan diri sendiri Hal tersebut menunjukkan adanya pergeseran nilai kemasyarakatan telah berubah tidak sesuai lagi dengan nilai budaya bangsa Indnesia, tidak sesuai lagi dengan nilai-nilai Pancasila sebagai pmersatu bangsa.

Pancasila sebagai dasar negara, pemersatu bangsa merupakan pedoman dalam kehidupan berbangsa dan bernegara. Pancasila yang berisi nilai Ketuhanan Yang Maha Esa, kemanusiaan yang adil dan beradab, persatuan Indonesia, kerakyatan yang dipimpin oleh hikmat kebijaksanaan dalam permusyawaratan perwakilan dan nilai keadilan sosial bagi seluruh rakyat Indonesia. Nilai-nilai yang terkandung dalam Pancasila harus

\footnotetext{
${ }^{1}$ M. Djamal, Fenomena Kekerasan di Sekolah, Pustika Pertiga, Yogyakarta, 2016.
} 
ditumbuhkembangkan kepada generasi muda penerus bangsa dalam menghadapi era globalisasi dan modernisasi agar tidak tergerus oleh nilai-nilai yang bertentangan dengan karakter bangsa.

Hadirnya kebebasan yang berlebihan (surflus of freedom) dan melemahnya aturan oleh negara (rule of law) telah melahirkan berbagai konflik kerukunan antara umat beragama, merebaknya penggunaan kekerasan dan kekuatan untuk menyelesaikan masalah. ${ }^{2}$ Keadaan tersebut mendorong peneliti untuk melakukan penelitian mengenai penguatan nilai persatuan bangsa dalam upaya mencegah kejahatan kekerasan .

Lima sila dalam Pancasila dijabarkan menjadi 36 butir pengamalan, sebagai pedoman praktis bagi pelaksanaan Pancasila. Butir-butir Pancasila diterapkan dalam ketetapan MPR No. II/MPR/1978 tentang Ekaprasetia Pancakarsa, yang berbunyi :

Sila Pertama : Ketuhanan yang Maha Esa

1. Percaya dan takwa kepada Tuhan yang Maha Esa sesuai dengan agama dan kepercayaan masing-masing menurut dasar kemanusiaan yang adil dan beradab.

2. Hormat menghormati dan bekerjasama antar pemeluk agama dan penganutpenganut kepercayaan yang berbeda-beda sehingga terbina kerukunan hidup.

3. Saling hormat-menghormati kebebasan menjalankan ibadah sesuai dengan agama dan kepercayaannya.

4. Tidak memaksakan suatu agama dan kepercayaan kepada orang lain.

Sila Kedua : Kemanusiaan yang adil dan beradab

1. Mengakui persamaan derajat, persamaan hak dan persamaan kewajiban antara sesama manusia.

2. Saling mencintai sesama manusia.

3. Mengembangkan sikap tenggang rasa.

4. Tidak semena-mena terhadap orang lain.

5. Menjunjung tinggi nilai-nilai kemanusiaan.

6. Gemar melakukan kegiatan kemanusiaan.

7. Berani membela kebenaran dan keadilan.

8. Bangsa Indonesia merasa dirinya sebagai bagian dari seluruh umat manusia, karena itu kembangkan sikat hormat menghormati dan bekerjasama dengan bangsa lain.

Sila ke tiga: Persatuan Indonesia

1. Mampu menempatkan persatuan, kesatuan serta kepentingan dan negara sebagai kepentingan bersama diatas kepentingan pribadi atau golongan.

2. Sanggup dan rela berkorban untuk kepentingan negara dan bangsa, apabila diperlukan.

3. Mengembangkan rasa cinta kepada tanah air dan bangsa.

4. Mengembangkan rasa kebanggaan berkebangsaan dan bertanah air Indonesia.

5. Memelihara ketertiban dunia yang berdasarkan kemerdekaan, perdamaian abadi dan keadilan sosial.

6. Mengembangkan persatuan Indonesia atas dasar Bhinneka Tungal Ika.

7. Memajukan pergaulan demi persatuan dan kesatuan bangsa.

${ }^{2}$ Rycho Amelza Dahniel, "Membangun karakter bangsa melalui Revitalisasi Nilai-nilai Pancasila dalam Fungsi Kepolisian Proaktif dari Perspektif Ilmu Kepolisian", Orasi Ilmiah dalam Rangka Dies Natalies Ke 33, UNLA tahun 2015 
Sila Ke Empat : Kerakyatan Yang Dipimpin Oleh Hikmat Kebijaksanaan Dalam Permusyawaratan/Perwakilan.

1. Sebagai warga negara dan warga masyarakat, setiap manusia Indonesia mempunyai kedudukan, hak dan kewajiban yang sama.

2. Tidak boleh memaksakan kehendak kepada orang lain.

3. Mengutamakan musyawarah dalam mengambil keputusan untuk kepentingan bersama.

4. Musyawarah untuk mencapai mufakat diliputi oleh semangat kekeluaragaan.

5. Menghormati dan menjunjung tinggi setiap keputusan yang dicapai sebagai hasil musyawarah.

6. Dengan itikad baik dan rasa tanggung jawab menerima dan melaksanakan hasil keputusan musyawarah.

7. Didalam musyawarah diutamakan kepentingan bersama di atas kepentingan pribadi atau golongan.

8. Musyawarah dilakukan dengan akal sehat dan sesuai dengan hati nurani yang luhur.

9. Keputusan yang diambil harus dapat dipertanggung-jawabkan secara moral kepada Tuhan Yang Maha Esa, menjunjung tinggi harkat dan martabat manusia, nilai nilai kebenaran dan keadilan, mengutamakan persatuan dan kesatuan demi kepentingan bersama.

10. Memberikan kepercayaan kepada wakil - wakil yang dipercayai untuk melaksanakan permusyawaratan.

Sila Ke lima : Keadilan Sosial bagi seluruh rakyat Indonesia

1. Mengembangkan perbuatan yang luhur, yang mencerminkan sikap dan suasana kekeluargaan dan kegotong-royongan.

2. Mengembangkan sikap adil terhadap sesama.

3. Menjaga keseimbangan antara hak dan kewajiban.

4. Menghormati hak orang lain.

5. Suka memberikan pertolongan kepada orang lain agar dapat berdiri sendiri.

6. Tidak menggunakan hak milik untuk usaha - usaha yang bersifat pemerasan terhadap orang lain.

7. Tidak menggunakan hak milik untuk hal - hal yang bersifat pemborosan dan gaya hidup mewah.

8. Tidak menggunakan hak milik untuk hal - hal yang bertentangan dengan atau merugikan kepentingan umum.

9. Suka bekerja keras.

10. Suka menghargai hasil karya orang lain yang bermanfaat bagi kemajuandan kesejahteraan bersama.

11. Suka melakukan kegiatan dalam rangka mewujudkan kemajuan yang merata dan keadilan sosial.

Pancasila sebegai pemersatu bangsa, untuk itu nilai-nilai yang terkandung harus tertanam dalam khidupan bangsa. Kekerasan yang terjadi akhir-akhir ini, tentu tidak sesuai dengan butir-butir Pancasila, kekerasan juga terjadi dilingkungan sekolah. ${ }^{3}$ Pancasila harus terus dihayati dan diamalkan untuk membangun karakter bangsa merupakan salah satu agenda penting yang diangkat dalam RPJPN 2005-2025 sebagaimana diundangkan dalam Undang-undang Nomor 17 tahun 2007 tentang RPJPN 2005-2025.

\footnotetext{
${ }^{3}$ M. Djamal, op. cit, hlm. 113-216
} 
Kata "pemersatu" mengandung pengertian adanya sesuatu unsur yang memberi pengaruh terhadap bersatunya unsur-unsur yang berbeda-beda dan terpisah-pisah. Dalam lingkup kehidupan berbangsa dan bernegara, bersatunya etnik dan budaya yang berbeda itu kecuali disebabkan oleh faktor kehendak bersama, juga karena adanya nilai-nilai yang merupakan etika lokal itu kemudian diangkat dan diselaraskan menjadi nilai-nilai bersama, untuk kemudian dijadikan sebagai falsafah hidup bersama dalam lingkup kebangsaan Indonesia, yaitu Pancasila. ${ }^{4}$

Dalam pemahaman tersebut maka nilai-nilai kebangsaan yang bersumber dari falsafah Pancasila pada hakikatnya adalah unsur-unsur yang dapat mendekatkan dan merekatkan segala perbedaan dimaksud, sehingga terjadi harmonisasi atau keselarasan hubungan sosial diantara elemen-elemen masyarakat menuju terwujudnya satu kesatuan bangsa Indonesia. Karena itulah maka Pancasila dengan segenap nilai yang terkandung didalamnya pada hakikatnya adalah pemersatu bangsa Indonesia.

Originalitas penelitian, terkait dengan kejahatan kekerasan yang semakin marak saat ini, sangat memperihatinkan, kekerasan yang terjadi di sekolah yang dilakukan oleh siswa atau guru ataupun kekerasan yang terjadi di masyarakat, sehingga menarik untuk diteliti. Kemudian setelah dilakukan penelusuran di perpustakaan Unla dan diluar Unla seperti di Unpas dan Unisba, juga melalui google/internet tidak diketemukan penelitian yang serupa dengan penelitian ini, yang diketemukan mengenai Pancasila sebagai pemersatu bangsa atau Pancasila sebagai pemersatu bangsa atau Pancasila sebagai ideologi ada dalam bentuk buku atau makalah-makalah tetapi yang melakukan penelitian mengenai penguatan Pancasila sebagai pemersatu bangsa dalam upaya mencegah kejahatan dengan kekerasan belum pernah ada yang meneliti.

\section{Identifikasi Masalah}

Bertitik tolak dari latar belakang diatas maka Penulis mengidentifikasikan masalah sebagai berikut :

1. Bagaimanakah implementasi penguatan Pancasila sebagai pemersatu bangsa dalam upaya mencegah kejahatan dengan kekerasan?

2. Bagaimana kendala penguatan Pancasila sebagai pemersatu bangsa dalam upaya mencegah kejahatan dengan kekerasan?

\section{TINJAUAN PUSTAKA}

\section{Pancasila Sebagai Pemersatu Bangsa}

Negara Indonesia memiliki perbedaan suku budaya, golongan, bahasa, politik dan perbedaan agama. Dalam kehidupan bermasyarakat, berbangsa dan bernegara tentu terdapat perbedaan tujuan dan kepentingan, maka Pancasila sebagai pemersatu bangsa tidak lepas dari konsepsi bahwa suatu Negara mutlak memeiliki suatau dasar Negara yang merupakan rambu atau pedoman kehidupan bermasyarakat, berbangsa dan bernegara.

Sila ketiga dari Pancasila yaitu Persatuan Indonesia menunjukkan adanya pemahaman bahwa perbedaan adalah suatu kekayaan yang harus dijunjung tinggi dengan mengutamakan persatuan dan kesatuan bangsa di atas kepentingan pribadi, golongan dan daerah. Barometer adalah kepentingan nasional, dan bukan kepentingan yang lebih kecil, lebih rendah, ataupun lebih sempit. Persatuan bangsa sesungguhnya nilai luhur yang harus

\footnotetext{
${ }^{4}$ Lemhanas, Nilai-nilai kebangsaan yang bersumber dari Pancasila, Jakarta 2015, hlm. 92
} 
dijunjung tinggi oleh semua umat manusia, karena pada hakekatnya perpecahan atau pertikaian akan menghancurkan bangsa itu sendiri. ${ }^{5}$

Pancasila sebagai pemersatu bangsa, pandangan ini menjelaskan bahwa Pancasila mempunyai dasar kesatuan yang mutlak berupa sifat kodrat manusia dalam kenyataan yang sewajarnya sebagai mahkluk individual dan sosial. ${ }^{6}$ Kedudukan dan fungsi Pancasila sebagai pemersatu bangsa akan memerankan Pancasila berikut ini $:^{7}$

1. Pancasila sebagai jiwa bangsa Indonesia

Artinya Pancasila merekat erat pada kehidupan bangsa Indonesia, dan menentukan eksistensi bangsa Indonesia. Segala aktifitas kehidupan bangsa Indonesia disemangati oleh Pancasila.

2. Pancasila sebagai Kepribadian bangsa Indonesia.

Artinya sikap mental tingkah laku dan amal perbuatan bangsa Indonesia memiliki ciri-ciri khas yang membedakan dengan bangsa-bangsa lain.

3. Pancasila sebagai pandangan hidup bangsa Indonesia.

Artinya nilai-nilai yang terkandung dalam Pancasila sebagai petunjuk, penuntun dan pegangan dalam mengatur sikap dan tingkah laku manusia Indonesia dalam kehidupan bermasyarakat, berbangsa dan bernegara.

4. Pancasila Sebagai Falsafah Hidup Bangsa Indonesia

Artinya Pancasila diyakini benar-benar memiliki kebenaran. Falsafah berarti pandangan hidup, sikap hidup, tuntunan hidup.

5. Pancasila sebagai weltanshaung bangsa atau sebagai Philosophische grondslag.

Artinya bangsa Indonesia atau Pancasila sebagai perjanjian luhur rakyat Indonesia melalui perdebatan dan tukar pikiran para pendiri Negara.

Pancasila menjadi pedoman bagi kehidupan kenegaraan dan hukum dalam konkretnya tidak hanya cita-cita dalam abstraknya, tetapi juga memiliki bentuk dan isi yang formal dan materiel untuk menjadi pedoman hidup kenegaraan dan hukum Indonesia dalam konkretnya. ${ }^{8}$

\section{Kejahatan Dengan Kekerasan}

Kejahatan adalah suatu konsep yuridis berarti tingkah laku manusia yang dapat dihukum berdasarakan hukum pidana. ${ }^{9}$ Kekerasan menurut Kamus Besar Bahasa Indonesia, diartikan sebagai : "Perbuatan seseorang atau sekelompok orang yang menyebabkan kerusakan fisik atau barang orang lain. ${ }^{10}$ Kekerasan atau violence merujuk pada tingkah laku yang pertama-tama harus bertentangan dengan undang-undang baik berupa ancaman saja maupun sudah merupakan suatu tindakan nyata dan memiliki akibatakibat kerusakan terhadap harta benda atau fisik atau mengakibatkan kematian ${ }^{11}$. Bentukbentuk kejahatan dengan kekerasan yaitu :

5 Hamid Darmadi, Eksistensi Pancasila Dan Undang-Undang Dasar 1945 Sebagai Pemersatu Bangsa, Alfabeta Bandung, 2017, hlm. 206

${ }^{6}$ Diasmo Sandi Swandara, Pokok-Pokok Pemikiran Notonegoro Tentang Pancasila, Prisma Jurnal Pemikiran Sosial Ekonomi Vol. 37, No. 2, Tahun 2018, hlm. 191

${ }^{7}$ Hamid Darmadi, op.cit, hlm. 210-212

8 Zulkarnaen, Dinamika Sejarah Hukum dari Filosofi hingga Profesi Hukum, Pustaka Setia Bandung 2018, hlm.

${ }^{9}$ Romli Atmasasmita, Bangsa Rampai Kriminologi, Rajawali Jakarta 1984, hlm. 31

${ }^{10}$ Departemen Pendidikan dan Kebudayaan, Kamus Besar Bahasa Indonesia, Balai Pustaka Jakarta, 1989, hlm. 425

${ }^{11}$ Romli Atmasasmita, Teori dan Kapita Selekta Krminologi, Refika Aditama Bandung, 2005, hlm. 66 

a. Pembunuhan (murder)
b. Perkosaan (rape)
c. Penganiayaan (aggravated assault)
d. Perampokan bersenjata (armed robbery)
e. Penculikan (kidnapping)

Kejahatan-kejahatan kekerasan tersebut digolongkan sebagai kejahatan kekerasan individual, yang termasuk kejahatan dengan kekerasan kolektif adalah perkelahian antar geng remaja yang menimbulkan kerusakan harta benda atau luka-lauka berat atau kematian. ${ }^{12}$ Ataupun kekerasan dalam rumah tangga (KDRT) yang meliputi ${ }^{13}$ :

a. Kekerasan fisik

b. Kekerasan psikis

c. Kekerasan seksual

d. Penelantaran rumah tangga

Kekerasan Dalam Rumah Tangga (KDRT) diatur dalam Undang-undang Nomor 23 Tahun 2014 Tentang Penghapusan Kekerasan Dalam Rumah Tangga. Rentan terjadinya kekerasan dalam rumah tangga adalah terhadap perempuan dan anak, misalnya masalah trafficking. ${ }^{14}$ Trafficking diatur dalam Undang-undang Nomor 21 Tahun 2007 Tentang Pemberantasan Tindak Pidana Perdagangan Orang (TPPO).

Kejahatan dengan kekerasan ada yang dikategorikan sebagai tindak pidana umum melanggar KUHP, tetapi ada juga yang dikategorikan ke dalam tindak pidana khusus melanggar di luar KUHP.

\section{Fakta Hukum Kejahatan Dengan Kekerasan}

Berita mengenai kejahatan dengan kekerasan tiap hari selalu ada kejadian, hal tersebut dapat diketahui dari media cetak maupun elektronik. Berikut ini peristiwa beberapa kejahatan dengan kekerasan :

1. Kekerasan disebabkan frustasi ekonomi

Ekonomi menjadi alasan penyebab terjadinya kekerasan pada anak. Rasa kefrustasian ekonomi sering menyebabkan orangtua dengan sadar melampiaskan apa yang dirasakannya kepada anak. Bukan hanya kekerasan biasa, bahkan bisa sampai berujung kematian. Kanja Isabel Putri, balita berumur 4 tahun ini diketahui meninggal dunia pada 4 Maret 2017 di Kampung Cikeas, Desa Nagrak, Kecamatan Gunung Putri, Kabupaten Bogor.

JJ (23) ayah tiri dan DY (20) ibu adalah orangtua yang tega menganiaya anaknya yang masih balita. Luka memar di kepala, dagu sobek dan lebam bahkan kaki melepuh adalah penderitaan yang dialami hingga korban meninggal. Padahal dua bulan sebelumnya, telah terjadi pembunuhan anak oleh orangtua kandung. Melihat kasus ini, peran masyarakat di sekitar juga sangat dipertanyakan. Bagaimana bisa masyarakat sekitar tidak peduli terhadap keselamatan anak-anak di lingkungannya. ${ }^{15}$

2. Diperkosa kemudian dibunuh

12 ibid

13 Ruslan Renggong, Hukum Pidana Khusus, Memahami Delik-Delik di Luar KUHP, Prenada Media Group Jakarta 2016 dan Rodliyah, Salim HS, Hukum Pidana Khusus, Unsur dan Sanksi Pidananya, Rajawali Pers, Jakarta 2017

14 LM. Gandhi Lapian, Disiplin Hukum yang Mewujudkan Kesetaraan dan Keadilan Gender, Yayasan Pustaka Obor Indonesia, Jakarta 2012

15 www.popmama.com, diakses 17 desember 2018 
Pada 28 April 2017, anak berusia 6 tahun dtemukan sudah tidak bernyawa oleh warga. Korban ditemukan di hutan kecil tidak jauh dari Sekolah Dasar Negeri 25 Sawang, Aceh Utara. Setelah mendapatkan informasi dan ditelusuri, korban meninggal akibat hendak mencoba melawan ketika diperkosa. Korban dicekik oleh pelaku hingga mengakibatkannya meninggal. Yang mengejutkan, pelaku ternyata adalah anak berusia 13 tahun berinisial $M$ yang tinggal sekampung dengan korban.

Dan parahnya, setelah membunuh korban, anak yang berhadapan dengan hukum ini sempat menunaikan shalat Jumát dan ikut mengevakuasi korban bersama dengan warga lain ke rumah duka. Bayangkan Ma, anak di bawah umur meninggal karena dibunuh oleh anak yang juga masih di bawah umur. Rasanya, tidak masuk akal. Bagaimana mungkin anak 13 tahun bisa melakukan hal seperti itu. ${ }^{16}$

3. Sakit hati ditagih utang, Pria di Jember Aniaya Korban Hingga Tewas

Sakit hati ditagih hutang, seorang pria di Jember, Jawa Timur, tega membunuh temannya dengan sadis. Korban bernama Latif, warga Desa Mumbulsari. Seperti ditayangkan Patroli Indosiar, Kamis (13/12/2018), pelaku tidak terima dengan perkataan korban yang dianggap menyinggung lalu menganiaya korban di bagian kepala, membenamkan tubuh korban ke lumpur hingga meregang nyawa.

Ironisnya, pelaku kemudian membawa kabur motor korban lalu dijual. Polres Jember akhirnya menangkap pelaku bernama Zaenal Abidin yang tak lain rekan sekaligus tetangga korban sesame pedagang sayur. Dari penyelidikan polisi, motif pembunuhan ini dilatarbelakangi sakit hati pelaku saat korban menagih hutang sebesar Rp. 300.000,- kepadanya.

Kasus pembunuhan ini terjadi pada tanggal 18 September 2018. Korban ditemukan tergeletak bersimbah darah di pinggiran sungai Kecamatan Silo dengan luka parah di kepala bagian belakang. Pelaku langsung kabur usai melakukan aksinya dan hampir tiga bulan menjadi buron. ${ }^{17}$

4. Deretan Aksi Geng Motor Yang Bikin Horor Jakarta

Baru-baru ini publik digegerkan dengan kejadian yang diduga dilakukan oleh geng motor di Kawasan Kemang, Jakarta Selatan. Lima orang menjadi korban perusakan oleh kelompok yang diduga geng motor Kemang, Jakarta Selatan. Keributan ini terjadi sekitar pukul 01.30 Wib dini hari tadi.

Ïya. Ada kejadian pengrusakan motor dan mobil. Dan beberapa warga ada yang dianiaya." tutur Kabid Humas Polda Metro Jaya di Mapolda Metro Jaya, Jakarta Selatan, Senin (5/3/2018). Menurut Argo, identitas kelima korban itu adalah Ari Pratama dengan cedera robek kecil di dagu, Viki Eko terluka di kepala, Dodi Januar Pribadi luka di bagian dagu, Mamat Rahmat memar kepala, dan Bayu Ardiansyah mengalami luka lecet di pipi.

"Empat kendaraan roda empat dirusak dan pecah kaca yang ada di lokasi depan kafe", jelas Argo. Aksi itu terekam dalam sebuah video yang kemudian viral di media sosial. Sekelompok pengendara motor berulah dengan melakukan aksi perusakan di wilayah Kemang, Jakarta Selatan. Sehari sebelumnya, seorang anggota Korps Brimob Polri atas nama Yasri Abdulmas (24) ditemukan tergeletak di kawasan Kemang, Jakarta Selatan, sektor lokasi perusakan diduga dilakukan geng motor. Pria berpangkat Bharada itu ditemukan dengan sejumlah luka tusuk di tubuhnya pada Minggu , 4 Maret 2018 sekitar pukul 04.00 Wib.

Öjek online datang ke Pos Polisi Kemang melaporkan ada keributan di depan Kafe Dronk. Setelah mendapat laporan, anggota Polri mendatangi ke lokasi dan dilihat

16 ibid

${ }^{17}$ Sumber : www.liputan6.com, diakses 17 Desember 2018 
korban sudah tergeletak di pinggir jalan." Tutur Argo. Warga sekitar lokasi mengaku tak mengenal para pelaku. Ïni yang geng motor bukan dari daerah sini," ujar pria penjaga warung di depan Dronk Café. ${ }^{18}$

Tabel

Banyaknya Kejahatan Menurut Kelompok Jenis Kejahatan, Tahun 2013-2016

\begin{tabular}{|c|c|c|c|c|}
\hline \multirow[t]{2}{*}{ Kelompok/Jenis Kejahatan } & \multicolumn{4}{|c|}{ Tahun } \\
\hline & 2013 & 2014 & 2015 & 2016 \\
\hline$(1)$ & $(2)$ & $(3)$ & $(4)$ & $(5)$ \\
\hline \multicolumn{5}{|l|}{ Kejahatan terhadap Nyawa } \\
\hline Pembunuhan & 1.386 & 1.277 & 1.491 & 1.292 \\
\hline \multicolumn{5}{|l|}{ Kejahatan Terhadap Fisik/Badan } \\
\hline Penganiyaan Berat & 15.958 & 13.996 & 14.664 & 14.468 \\
\hline Penganiayaan Ringan & 19.195 & 22984 & 22.981 & 21.155 \\
\hline Kekerasan Dalam Rumah Tangga & 9.837 & 9.386 & 9.483 & 11.083 \\
\hline \multicolumn{5}{|l|}{ Kejahatan Terhadap Kesusilaan } \\
\hline Perkosaan & 1.690 & 1.715 & 1.739 & 1.594 \\
\hline Pencabulan & 3.160 & 3.784 & 3.312 & 3.653 \\
\hline \multicolumn{5}{|l|}{ Kejahatan Terhadap Kemerdekaan Orang } \\
\hline Pencurian Dengan Kekerasan & 10.683 & 10.414 & 10.759 & 10.726 \\
\hline $\begin{array}{l}\text { Pencurian dengan Kekerasan menggunakan } \\
\text { Senjata Api }\end{array}$ & 482 & 332 & 312 & 272 \\
\hline $\begin{array}{l}\text { Pencurian dengan Kekerasan menggunakan } \\
\text { Senjata tajam }\end{array}$ & 880 & 1.012 & 785 & 1.097 \\
\hline \multicolumn{5}{|l|}{ Kejahatan Terhadap Hak Milik/Barang } \\
\hline Pencurian & 25.983 & 24.538 & 26.298 & 26.636 \\
\hline Pencurian Dengan Pemberatan & 46.064 & 42.699 & 41.100 & 46.277 \\
\hline Pencurian Kendaraan Bermotor & 42.508 & 42.165 & 38.389 & 37.871 \\
\hline Pengrusakan/Penghancuran Barang & 7.904 & 7.207 & 6.968 & 7.926 \\
\hline Pembakaran Dengan Sengaja & 572 & 788 & 721 & 650 \\
\hline Penadahan & 472 & 354 & 537 & 666 \\
\hline \multicolumn{5}{|l|}{ Kejahatan Terkait Narkotika } \\
\hline Narkotika dan Psikotropika & 19.953 & 19.280 & 36.874 & 39.171 \\
\hline \multicolumn{5}{|c|}{ Kejahatan terkait Penipuan, Penggelapan dan Korupsi } \\
\hline Penipuan/Berbuat Curang & 27.744 & 26.390 & 30.689 & 27.421 \\
\hline Penggelapan & 21.345 & 21.404 & 21.646 & 20.459 \\
\hline Korupsi & 537 & 814 & 1.780 & 1.318 \\
\hline \multicolumn{5}{|l|}{ Kejahatan Terhadap Ketertiban Umum } \\
\hline Terhadap Ketertiban Umum & 4.702 & 4.519 & 4.227 & 4.297 \\
\hline
\end{tabular}

Sumber : Biro Pengendalian Operasi, Mabes Polri ${ }^{19}$

18 Ibid

${ }^{19}$ Statistik Kriminal Tahun 2016 dan 2017, diakses 17 Desember 2018 


\section{PEMBAHASAN}

\section{Implemetasi Pengauatan pancasila sebagai pemersatu bangsa dalam upaya mencegah kejahatan dengan kekerasan.}

Kekerasan yang sering terjadi akhir-akhir ini tentunya sangat meresahkan, apalagi kekerasan yang berakhir dengan hilangnya nyawa dan kematian, sudah tidak sesuai lagi dengan norma agama, norma hukum dan norma sosial, sangat bertentangan dengan Pancasila sebagai dasar Negara.

Lima sila dalam Pancasila perlu terus diimlementasikan dalam kehidupan seharihari. Implemenstasi sila pertama yaitu Ketuhanan Yang Maha Esa, bahwa kita masyarakat Indonesia percaya dan bertakwa kepada tuhan Yang Maha Esa sesaui dengan agama dan kepercayaan masing-masing menurut dasar kemanusiaan yang adil dan beradab. Hormat menghormati, bekerjasama antar pemeluk agama dan penganut-penganut kepercayaan yang berbeda-beda sehingga terbina kerukunan hidup. Atas dasar iman dan takwa kepada tuhan Yang Maha Esa, tentu tidak dibenarkan perbuatan yang tercela, perbuatan yang semena-mena pada orang lain, meskipun berbeda keyakinan, kerukunan tetap dijaga.

Implementasi Sila Kedua : Kemanusiaan Yang Adil Beradab, yaitu mengakui persamaan derajat, persamaan hak dan persamaan kewajiban antar sesama manusia, mengembangkan sikap tenggang rasa, tidak semena-mena terhadap orang lain, menjungjung tinggi nilai-nilai kemanusiaan. Atas dasar sila tersebut, kekerasan tidak akan terjadi kalu setiap orang menghormati hak orang lain, mengakui persamaan derajat, saling menghormati tidak mudah tersinggung apalagi karena hal atau kejadian yang ringan tetapi berakhir dengan kekerasan. Peristiwa pembunuhan tidak sesuai rasa kemanusiaan yang adil dan beradab. Sila kedua ini perlu terus ditumbuh kembangkan kepada semua siswa, mahasiswa, orang tua dan masyarakat, kasus yang dibahas, pelaku kekerasan adalah anak di bawah umur. Sangat mencemaskan anak sebagai penerus generasi bangsa ini banyak yang terlibat dengan kekerasan, demikian pula perilaku orang tua yang tega melakukan kekerasan kepada anaknya sungguh merupakan perbuatan yang biadab, tidak memberikan contoh yang baik terhadap anak dan lingkungannya.

Implementasi Sila Ketiga, Persatuan Indonesia, yaitu mampu menempatkan persatuan, kesatuan, kepentingan Negara sebagai kepentingan bersama diatas kepentingan pribadi atau golongan. Sanggup dan rela berkorban untuk kepentingan Negara dan bangsa apabila diperlukan. Atas dasar tersebut kepada semua warga Negara Indonesia harus ditumbuhkembangkan rasa memiliki, cinta tanah air, memiliki rasa nasionalisme yang tinggi, bangga berkebangsaan Indonesia. Sehingga semua warga ingin memajukan persatuan dan kesatuan bangsa, turut memelihara ketertiban, mengisi kemerdekaan, perdamaian dengan perbuatan yang dapat mempersatukan bangsa. Sehingga tercipta Susana adil dan makmur, tentram kerta raharja, energy tidak terbuang untuk hal yang tidak bermanfaat, tidak terkuras untuk mengatasi konfilk membangun karena dirusak tetapi membangun untuk kemajuan bangsa. Implementasi sila Persatuan bangsa ini terus menerus dipupuk, sbegaia upaya mencegah kekerasan, sebagai bangsa yang beradab, slaing menyayangi sesame warga dalam ikatan sebangsa dan setanah air atas dasar Bhineka Tunggal Ika.

Implementasi sila keempat yaitu kerakyatan yang dipimpin oleh hikamt kebijaksanaan dalam permusyawaratan perwakilan. Sebagai warga Negara dan warga masyarakat yang mempunyai kedudukan, hak dan kewajiban yang sama, tidak boleh memaksakan kehendak kepada orang lain, mengutamakan musyawarah dalam mengambil keputusan untuk kepentingan bersama, musyawarah dilakukan untuk mencapai mufakat dengan semeagat kekeluargaan mengutamakan kepentingan bersama diatas kepentingan 
pribadi atau golongan. Dilakukan dengan akal sehat dan sesuai dengan hati nurani yang luhur yangd apat dipertanggungjawabkan secara moral kepada Tuhan Yang Maha Esa, menjunjung tinggi harkat martabat manusia, nilai-nilai kebenaran dan keadilan bertujuan mengutamakan persatuan dan kesatuan untyk kepentingan bersama. Dari sila ini dapat ditelaah setiap warga Negara untuk bisa mengendalikan diri, tidak mudah emosi karena segala sesuatu dimusyawarahakn secara kekeluargaan demikain juga untuk anak, orang tua dan masyarakat akan timbul rasa salaing menghormati pendapat yang lain meskipun berbeda dengan pendapatnya.

Implementasi sila kelima, Keadilan sosial bagi seluruh rakyat Indonesia yaitu mengembangkan perbuatan yang luhur dalam suasana kekeluargaan dan gotong royong, mengutamakan sikap adil terhadap sesame, menjaga keseimbangan antara hak dan kewajiban, menghormati hak orang lain, suka memberikan pertolongan kepada orang lain agar mandiri, tidak menggunakan hak milik untuk usaha-usaha yang bersifat pemerasan terhadap orang lain, tidak boros, tidak bergaya hidup mewah, tidak merugikan kepentingan umum, suka berkerja keras. Sila kelima ini perlu terus ditumbuhkembangkan maulai sejak usia dini sehingga nanti di masa remaja atau dewasa sudah memiliki sifat terpuji. Tidak melakukan hal yang bertentangan dengan kepentingan umum. Setiap warga Negara akan menghasilkan karya, kreatifitas yang tinggi bermanfaat bagi kemajuan dan kesejahteraan bersama dalam rangka mewujudkan keadilan sosial yang merata. Atas dasar hal tersebut, kekerasan yang marak akan semakin dapat diminimalisir atau dihilangkan sama sekali karena butir-butir Pancasila dilaksankan dalam kehidupan.

Pancasila telah ditanamkan sejak Sekolah Dasar sampai dengan perguruan Tinggi. Untuk siswa SD ada mata pelajaran PPKN (Pendidikan pancasila dan Kwewargnegaraan) yang intinya mengajarkan, menumbuhkembangkan penghayatan dan mengamalkan nilainilai pancasila dalam kehidupan sehari-hari, sehingga terwujud masyarakat yang adil dan makmur. Demikian pula di tingkat mahasiswa ada mata kuliah Pancasila dan Pendidkan Kewarganegraan.

\section{Kendala Penguatan Pancasila Sebagai Pemersatu Abngsa Dalam Upaya Mencegah Kejahatan Dengan Kekerasan.}

Kendala yang dihadapi dalam penguatan Pancasila sebagai pemersatu Bangsa, dalam upaya mencegah kejahatan dengan kekerasan, peneliti menganlisis menjadi dua (2) faktor berdasarkan temuan dan hasil wawancara serta telaah secara teoritik dan praktik, yaitu :

\section{Faktor Internal}

Faktor internal merupakan faktor dari dalam diri pelakau kekerasan dapat berupa pendidikan, ekonomi dan sosial, sitem pendidikan masih meilhat kesuksean. Pendidikan adalah nilai akademik maka kekerasan yang terjadi di sekolah bukan kesalahan secara sitematik, yang seharusnya intropeksi. Kekerasan yang terjadi merupakan akibat minimnya penddikan di Indonesia melihat regulasi piker dan kendali emosi, peserta didik cenderung kurang dihargai dan diberi apresiasi saat berada di sekolah. Ketika tidak pernah dihargai maka merekapun akhirnya tidak bisa mneghargai, menghormati dan mengapresiasi orang lain.

Pendidkan belum berorientasi pada manusia, tetapi terlalu fokus pada pencapaian nilai akademik serta kepatuhan pada standar di sisi dokumen. Pendidikan uga harus lebih mengarahkan perilaku budi pekerti saling menghargai, menghormati orang lain.

Pancasila lahir digali dari kepribadian bangsa Indonesia, yaitu kekeluargaan yang harmonis, adanya keseimbangan antara kepentingan individu fengan kepentingan umum, 
menjungjung tinggi norma-norma hukum dan moral hingga memperlakukan orang lain secara adil dan beradab. Sebagai bangsa yang ramah menjungjung tinggi nilai-nilai agama, berprilaku sesuai tuntutan agama, maka dengan pendidikan akan menghasilkan manusia yang berakhlak mulia.

Faktor ekonomi dan sosial juga merupakan kendala dalam upaya penguatan, sulitnya lapangan kerja yang tidak sesuai dengan keahlian, dari Negara agraris ke negara industry tentu menghasilkan pengangguran, pengangguran akan menimbulkan kejahatan. Adanya kesenjangan ekonomi dan sosial juga sangat berpengaruh, gara-gara uang sedikit saja dapat memicu perkelahian. Sikap atau perilaku yang konsumtif, menginginkan barang mewah tanpa kerja keras tanpa usaha yang ulet menghadapi suasana yang serba modern menimbulakn kekerasan. Di era milenial ini dituntut untuk ketja keras dan kreatifitas yang tinggi untuk kemanfaatan dan kemajuan bersama.

\section{Faktor Eksternal}

Maraknya kekerasan semakain merebak karena faktor media sosial yang mudah menyebarkan pelanggaran atau kekerasan, sehingga bagi orang atau siswa menjadi lebih berani melakukan kekerasan pada orang lain, hukuman bagi siswa atau pelanggar atau pelaku kekerasan tidak membuat malu dan jera. Pengaruh negatif membuat orang mudah meniru melakukan perilaku menyimpang. Media sosial seyogyanya membuat lebih mudah berinteraksi, membuat orang lebih kreatif, media sosaial yang sangat bebas memeudahkan setiap orang memproduksi informasi apa saja dan kapan saja. Setiap orang bisa membuat konten apa saja sesuai yang diinginkan. Tetapi kadang-kadang di media sosial fakta sering dikalahkan oleh opini, untuk itu media sosial harus mencerahkan memberikan literasi yang berkeadaban sesuai dengan nilai-nilai Pancasila. Media sosial harus berisi konten-konten yang membangkitkan semangat untuk membangun sesuai dengan jati diri bangsa Indonesia.

\section{PENUTUP}

\section{Kesimpulan}

1. Penguatan Pancasila sebagai pemersatu bangsa yang diimplementasikan dalam kehidupan bermasyarakat berbangsa dan bernegara untuk meminimalisir kejahatan dengan kekerasan, melalui sistem pendidikan belum berorientasi pada manusia yang berkarakter atau akhlak mulia, tetapi berorientasi pada sistem nilai akademik semata.

2. Kendala penguatan Pancasila sebagai pemersatu bangsa dalam upaya mencegah kejahatan dengan kekerasan, meliputi kendala internal yaitu pendidikan dan ekonomi sosial. Kendala eksternal yaitu pengaruh negative media sosial.

\section{Saran}

1. Penguatan Pancasila sebagai pemersatu bangsa perlu terus ditumbuhkembangkan kepada seluruh lapisan masyarakat sejak usia dini.

2. Penataan kembali kurikulum harus berorientasi pada pendidikan karakter yang bertujuan memiliki akhlak mulia.

\section{DAFTAR PUSTAKA}

M. Djamal, Fenomena Kekerasan di Sekolah, Pustika Pertiga, Yogyakarta 2016

Rycho Amelza Dahniel, "Membangun karakter bangsa melalui Revitalisasi Nilai-nilai Pancasila dalam Fungsi Kepolisian Proaktif dari Perspektif Ilmu Kepolisian", Orasi Ilmiah dalam Rangka Dies Natalies Ke 33, UNLA tahun 2015 
Hamid Darmadi, Eksistensi Pancasila Dan Undang-Undang Dasar 1945 Sebagai Pemersatu Bangsa, Alfabeta Bandung, 2017

Diasmo Sandi Swandara, Pokok-pokok Pemikiran Notonegoro Tentang Pancasila, Prisma Jurnal Pemikiran Sosial Ekonomi Vol. 37, No. 2, Tahun 2018

Zulkarnaen, Dinamika Sejarah Hukum dari Filosofi hingga Profesi Hukum, Pustaka Setia Bandung 2018

Romli Atmasasmita, Bangsa Rampai Kriminologi, Rajawali Jakarta 1984

Departemen Pendidikan dan Kebudayaan, Kamus Besar Bahasa Indonesia, Balai Pustaka Jakarta, 1989

Romli Atmasasmita, Teori dan Kapita Selekta Krminologi, Refika Aditama Bandung, 2005

Ruslan Renggong, Hukum Pidana Khusus, Memahami Delik-Delik di Luar KUHP, Prenada Media Group Jakarta 2016 dan Rodliyah, Salim HS, Hukum Pidana Khusus, Unsur dan Sanksi Pidananya, Rajawali Pers, Jakarta 2017

L.M. Gandhi Lapian, Disiplin Hukum yang Mewujudkan Kesetaraan dan Keadilan Gender, Yayasan Pustaka Obor Indonesia, Jakarta 2012

I Made Paseh Pinantha, Metodologi Penelitian Hukum Normatif Dalam Justifikasi Teori Hukum, Kencana Jakarta 2017

Lemhanas, Nilai-nilai kebangsaan yang bersumber dari Pancasila, Jakarta 2015

Undang-undang Nomor 17 tahun 2007 tentang RPJPN 2005-2025

TAP MPR No. II/MPR/1978 tentang Ekaprasetia Pancakarsa 